\title{
India's Season of Dissent: An Interview with Poet Karthika Naïr
}

Laetitia Zecchini and Karthika Naïr

\section{(2) OpenEdition \\ Journals}

Electronic version

URL: http://journals.openedition.org/samaj/6651

DOI: 10.4000/samaj.6651

ISSN: 1960-6060

\section{Publisher}

Association pour la recherche sur l'Asie du Sud (ARAS)

Electronic reference

Laetitia Zecchini and Karthika Naïr, «India's Season of Dissent: An Interview with Poet Karthika Naiir », South Asia Multidisciplinary Academic Journal [Online], 24/25 | 2020, Online since 28 October 2020, connection on 15 December 2020. URL : http://journals.openedition.org/samaj/6651 ; DOI : https:// doi.org/10.4000/samaj.6651

This text was automatically generated on 15 December 2020 .

\section{(c) (i) (9)}

This work is licensed under a Creative Commons Attribution-NonCommercial-NoDerivatives 4.0 International License. 


\title{
India's Season of Dissent: An Interview with Poet Karthika Naïr
}

\author{
Laetitia Zecchini and Karthika Naïr
}

\section{Ghazal: India's Season of Dissent}

This year, this night, this hour, rise to salute the season of dissent. Sikhs, Hindus, Muslims-Indians, all-seek their nation of dissent.

We the people of...they chant: the mantra that birthed a republic. Even my distant eyes echo flares from this beacon of dissent.

Kolkata, Kasargod, Kanpur, Nagpur, Tripura... watch it spread, tip to tricoloured tip, then soar: the winged horizon of dissent.

Dibrugarh: five hundred students face the CAA and lathiwielding cops with Tagore's song-an age-old tradition of dissent.

Kaagaz nahin dikhayenge... Sab Kuch Yaad Rakha Jayega...

Poetry, once more, stands tall, the Grand Central Station of dissent.

Aamir Aziz, Kausar Munir, Varun Grover, Bisaralli...

Your words, in many tongues, score the sky: first citizens of dissent.

We shall see/ Surely, we too shall see. Faiz-saab, we see your greatness scanned for "anti-Hindu sentiment", for the treason of dissent.

Delhi, North-East: death flanks the anthem of a once-secular land where police now maim Muslims with Sing and die, poison of dissent.

A government of the people, by the people, for the people, has let slip the dogs of carnage for swift excision of dissent. 
Name her, Ka, name her. Umme Habeeba, mere-weeks-old, braves frost and fascism from Shaheen Bagh: our oldest, finest reason for dissent.

This ghazal was composed by Karthika Naïr. Born in Kerala, the poet moved to France in 2000, subsequently working for several cultural institutions (Cité de la Musique, Centre national de la danse, Musée national de l'histoire de l'immigration...) as a dance producer, dance-writer, or "dance enabler," as she sometimes likes to define herself. Her closest associations have been with choreographers Sidi Larbi Cherkaoui, Damien Jalet and Akram Khan. ${ }^{1}$ She published three collections of poetry; Bearings in 1999; Until the Lions, Echoes from the Mahabharata in 2015, which won the Tata Literature Live ! Book of the Year 2015 (for fiction), ${ }^{2}$ and Over \& Underground in Paris and Mumbai, in 2018, coauthored with poet Sampurna Chattarji and the artists Joëlle Jollivet and Roshni Vyam. With Joëlle Jollivet, she also brought out a children's book, The Honey Hunter/Le Tigre de Miel, first published in 2013 and translated into French, German and Bangla.

1 Her poignant retelling of the Mahabharata in Until the Lions, Echoes from the Mahabharata, is "among other things, a passionate antiwar manifesto," as David Shulman recently suggested. ${ }^{3}$ The epic is recast from the perspective of those who have been promised to erasure and are often the first casualties of war: the faceless, the nameless and unremembered by/of history, many of whom are women (spouses, lovers, mothers, sisters, etc...). The "echoes" of the Mahabharata are not only the echoes of all the other Mahabharatas in whose lineage Karthika Naïr places herself, the ocean of stories and (re)tellings to which the epic continues to give birth. Her poems' unflinching confrontation with the violence of the world, and of India in particular, are about today. In the powerful, damaged and enraged voices of those who refuse to be muted or unaccounted, we hear echoes of the struggles of Dalits, Adivasis, women, Muslims, but also of all the other (increasingly) threatened minorities whose dissenting views and narratives infuriate the sentinels of cultural and religious majoritarianism: activists, journalists, students, artists, writers...

2 In her recent introduction to the American edition of Until the Lions, Karthika Naïr writes:

By $2015,{ }^{4}$ casualties were not statistics anymore, reported with increasing urgency by PEN or FreeMuse. They were names, faces, voices you knew, had read, watched, heard. Some, those first met when young-in the flesh, or through words, chords, images-and dearly loved. Artists, writers, activists: some whose work, whose life had powered your own, from near or far. People who had merely gone out one day to celebrate art and debate, laughter and sport. Narendra Dabholkar. Ahmed Rajib Haider. Gulnar (Muskan). Bernard Maris. Govind Pansare. Avijit Roy. 21 visitors to Bardo National Museum. H Farook. M Kalburgi. Francisco Hernández. 89 music lovers attending an Eagles of Death Metal gig at Bataclan. The living are targeted in other ways. With book bans. Prison. Exile. Fatwa. Smear campaigns. Accusations of sedition... Kamel Daoud. Oleg Sentsov. Perumal Murugan. Atena Farghadani. Fatima Naoot. The 50-odd Indian writers (followed by film-makers and artists) - who had returned awards and honors as protest against the spate of murders of intellectuals and minoritieshounded as anti-nationals by several media houses and right-wing politicians ${ }^{5}$

It was perhaps only natural that Karthika Naïr, who considers herself a political poet (or rather: "how can literature not be political?") would be moved to write on Shaheen Bagh, when in December 2019, a handful of Muslim women came out of their homes in 
Delhi to protest against the Citizenship Amendment Act, and resolved not to move before they were heard. Shaheen Bagh was also a peaceful resistance to and against violence: the violence to which Muslims and women have been subjected for so long in India; the violence unleashed at the Jamia Millia University campus a few days earlier, and the constant threat of violence (by the police and by right-wing "goons") to which the protestors were subjected during the one-hundred days during which the sit-in lasted. The "dogs of carnage" summoned by Karthika Naïr in her ghazal, eventually broke loose, unleashing terror in the streets of Delhi. But what happened at Shaheen Bagh is and must be remembered. And the task of the poet is also to make sure that these voices continue to be heard.

In the following interview conducted over Skype, and revised over email in September 2020, we talk of Shaheen Bagh and of her poem "Ghazal: India's Season of Dissent; of the activism of Indian writers and artists; of the politics of literature; of the relevance of poetry to protest movements and resistance struggles; of how literary texts can "respond" to violence, grief and pain. And since Karthika Naï's poetry and biography constantly weave together a multitude of contexts, voices, and cultural backgrounds, she also throws light on the interconnection and intersectionality of these struggles; on the resonances of the anti-CAA protests and of Shaheen Bagh outside India; on how terror and resistance to terror are echoed in different parts of the world.

\section{Interview}

LZ: Let us begin with your poem, "Ghazal: India's Season of Dissent." Could you tell us about the circumstances behind the writing of this text... Without its being a "commissioned piece," you were also responding to a request or an invitation, weren't you?

$\mathrm{KN}$ : I think for those of us who are familiar with what has been taking place in India for the past few years, it was unfortunately something that we had been bracing ourselves for, the CAA, and the NRC, etc. But I don't think anyone thought it would be happening with such speed. Ever since all these things have been happening, I had been watching everything I could, and reading outstanding writer-journalists-Mukul Kesavan, Samanth Subramanian, Nilanjana Roy, Raghu Karnad and more, some of them dear friends-who were out there, on the terrain, either covering the events or trying to contribute, or helping the victims after the attacks. So I was very much keeping in touch, but I was also very ambivalent about writing about things that I was at a distance from. Whatever I was going to write, I thought there needed to be clarity and absolute honesty, even within the work, about positioning the gaze: my gaze. Because I was certainly an outsider, physically safe, in the context of Shaheen Bagh. I thought it was important to make that distinction, because it is problematic to appropriate or even claim allegiance, when the allegiance is easy. Because the allegiance of those who were out there-including many people whom I know, admire or care for-and who were defending their and my definition of a democracy, comes at a physical cost. So many were detained, harmed, threatened. They bear the mark of their allegiance on their bodies, on their selves.

That's just a detour to say that I had been wanting to write about the protests and the situation in India, but not sure in which capacity I could. And then Salil (Tripathi) ${ }^{6}$ put me in touch with Sofia Karim, a visual artist and the niece of award-winning photographer and human rights activist from Bangladesh, Shahidul Alam. She was 
preparing an installation at the Tate Modern, in the Turbine Hall, which was called "TurbineBagh," and was also an extension of something she had done when her uncle was in prison, using her artwork in the campaign to free him. . She was planning an evening at the end of March where artists, participants, viewers, everyone who wanted, would be invited to join this protest to "stand in solidarity with mass protests across India." They would also be given these food bags with poetry or art on it. That was the performance itself. All this was before the pandemic broke out and before Shaheen Bagh was dismantled. And what I liked about it was that it was going to be part of a larger action, that it was both ephemeral and durable. There was also a real sense of people congregating, which I have great faith in, rather than being a petition or just an online thing, all of which are necessary but all too intangible.

It also allowed me to write from my position, and from the position of all these people who, like me, are far away but want to express their solidarity. So this invitation gave me the opportunity to chronicle what I could see from a distance, and what that meant to me also in terms of everything that I had previously grown up with, or taken for granted, like the right to protest, which is now threatened in India and in so many other parts of the world.

LZ: From Shaheen Bagh in Delhi, to Turbine Bagh in London, we also witness an internationalization of struggles that are staged or made visible in different parts of the world. And Shaheen Bagh captured worldwide media attention. I was also thinking of a recent appeal by some prominent world intellectuals who have urged the release of writers and activists Varavara Rao and G. N. Saibaba. ${ }^{\mathbf{8}}$ You yourself have been very much a part of many of these international campaigns to free writers, journalists, activists. But going back to what you were saying about "petition activism," these campaigns and the media attention can both give incredible visibility, perhaps agency, but can conversely also highlight a form of powerlessness...So, for instance, Varavara Rao who is 80 years old and was diagnosed with Covid, and G.N. Saibaba who is $90 \%$ handicapped, are still in prison and their lives, as we speak, are at risk. That is a question we'll keep returning to, no doubt. But what can these campaigns and petitions do? How does that kind of activism help?

$\mathrm{KN}$ : I think we need to be very clear about what petitions can do, and what they can't. The best thing they can do is, indeed, visibilize. It may be never immediate enough, of course. But there is a specific end and one can manage to have a cumulative movement which gathers force from both physical real-life presence and mobilization, and campaigns or petitions that are internationalized. One of the best examples of that I would say is actually Shahidul Alam's liberation from a Dhaka prison, where people in situ but also people from all around the world put enormous pressure.

I do think that petitions are useful to that extent, inasmuch as they create awareness, give visibility, disseminate knowledge and information about certain cases, and help people use other platforms as well to protest, or dissent or demand. And in certain happy cases, it is generating enough of a momentum...But there are also worrying aspects as well: one, with the profusion of online appeals, there is the danger of, shall we call it, petition fatigue; the other, of petitions generating the false and easy reassurance that we've done our bit with a click on a button, that nothing more is required.

LZ: If we return to your ghazal, you've said that poetry has a treasure trove of forms at its disposal, and that these forms have specific functions-that they do different things, and are chosen for what they can do. In the context of Shaheen Bagh and the persecution of 
Muslim minorities in India, the choice of a ghazal seems both formal and political. Would you like to elaborate a little?

$\mathrm{KN}$ : Of course. Well there are many reasons why I chose this specific form. One of which is also heritage. And the people that I quote or that inspire me here, are people like Faiz Ahmad Faiz, Ali Sardar Jafri, Sahir Ludhianvi, Firaq Gorakhpuri and Kafi Azmi. The ghazal has an extraordinary history, and an enormous capacity for expansion, it can contain everything from a love song, with which it is (sometimes unfortunately) most famously associated, to an anthem: it has been the instrument of so much reflection, protest, and dissent. I was again inscribing myself in that literary and activist lineage, in that tradition of dissent.

LZ: You've also said that forms are your weapons...

$\mathrm{KN}$ : Yes, but in this particular context I wanted to inscribe myself in this lineage of the ghazal as an activist writer's tool, or basically as a writer's tool. Because like Arundhati Roy says, that's a bit of a tautology "activist writer." When you are a writer, you are political. To state the obvious, for a writer to say I am not political, for me, is also extremely political, because it means that you are so privileged that you don't have to have any politics. So, the ghazal was a great way to inscribe myself in a tradition and say, again, that this kind of literary activism is nothing new. It is part of something that has been going on for ever so long, which is that literature, or poetry, is a way of situating yourself in society, in a nation, on a globe just as much as it is of situating yourself inside a body or a heart. And how you situate yourself in a body is probably the first political thing you do.

Going back to the ghazal, it's a form which really lends itself to sort of hammering the same theme but with variations. You've got the radif (refrain word or phrase, which corresponds here to the word "dissent") and you've got the qafiya (the rhyming pattern that must precede the radif). ${ }^{9}$ Imagine drawing loops of the same size, in the air, each distinct, but touching the same point on the floor-so the point of landing will be identical each time, though the curve will be different. I also love the fact that the couplets which have the same refrain, and the same meter, are selfcontained, but that the change in rhyming words can allow the development of a thought, an idea with each successive couplet.

LZ: One of the things I find so compelling in your work is how you indeed situate yourself and your texts in the turmoil of the political and social world, but also in a world of texts. And it's both at the same time, all the time, inseparably. In your ghazal you quote a line from Faiz' famous nazm "Hum Dekhenge." His poetry and these lines were very much part of the protests at Shaheen Bagh, right? And perhaps one of the reasons why Shaheen Bagh became such an iconic space was obviously because it represented an extraordinary instance of women-led grassroots mobilization, but also because it became a space of extraordinary creativity. Art and literature were mobilized; ordinary citizens, activists, artists, singers, students seemed to be united in a language, a performance, and a reclamation of protest. So how do you relate to what happened there? Do you believe this was indeed one of the specificities of Shaheen Bagh?

$\mathrm{KN}$ : What was most wonderful I think was actually that it was not specific or peculiar. In the sense that, yet again, whether it's the racial, equal rights, issues, the independence movement, or other struggles, poetry and art in a larger sense have always been part of these protests. They have always been part of civil society's reclamation of justice. What is maybe peculiar is the fact that this has finally caught the larger imagination. Perhaps because of literature, poems were being spoken and 
not just written, and going viral, through Internet. That's again a reminder of this tremendous function poetry has.

LZ: You've got this wonderful line in the poem, "Poetry, once more, stands tall."

$\mathrm{KN}$ : Yes, and I think what has got forgotten is that it's an oral form, perhaps the oral form par excellence, and that it has been part of many, many, great movements. You see, they were all outliers, the Sufi, bhakti poets, freedom fighters. You take any regional, national, religious movement of dissent or reform, poetry's been there. So here, at Shaheen Bagh, I think we were seeing that poetry came out of the books/ notebooks, came out of this misconception that it's an elitist art and took its place on the street... A lot of the poets I quoted, you know, Aamir Aziz, Kausar Munir, Varun Grover, Bisaralli were all out there, in Delhi, Bombay, smaller cities, in the streets, on the platforms, reciting, chanting, improvising. And that's again a tradition which it was high time we brought back. And it's just fantastic that it was their words that were being echoed, and translated across the country. "Kaagaz nahin dikhayenge" went into English, Tamil and many other languages. That was quite inspiring from far away. Have you seen that video where Kausar Munir speaks in three different languages, Hindi, Urdu, English, in the same poem, and also talks about her grandfather who made that choice to stay on in India after Partition? ${ }^{10}$ The case she makes is: "How do you divide or even define an identity."

And I think Faiz's "Hum dekhenge" is the finest example of something that crosses continents, borders, languages. The funniest part actually, and it's bitter, bitter humor, but when the dead Faiz gets involved in a case of "anti-Hindu sentiments," then you know that the country is really in a ridiculous state. ${ }^{11}$

LZ: Perhaps we can explain briefly the intertextual fabric of this poem. So you have the first words from the Preamble to the Constitution of India ("We the People of India ...") that was meant to spell out the principles of justice, fraternity and liberty on which the Constitution was laid; you spoke about Faiz and his iconic poem "Hum dekhenge" ("We shall see"); lines from a poem Aamir Aziz released after the brutal attacks on the Jamia Millia and JNU Campus, "sab yaad rakha jayega" ( We will remember it all12); lines of another poem which became an anthem of dissent from lyricist and actor Varun Grover, "kaagaz nahin dikhayenge" (the-NRC-papers we won't show). And you also quote the name of Kannada poet Siraj Bisarelli, whose recitation of an anti-CAA poem (echoing and inverting Varun Grover's earlier text) "When will you show your papers," led to his arrest. Are there any other references or "echoes" you would like to highlight?

KN: Yes. The third couplet names some of the far-flung or smaller cities, states (as well as Kolkata, which has its own proud tradition of dissent) that don't always get talked about in national media for the right reasons, but were all chronicled in the press as having had widespread, sustained movements of resistance. And the fourth couplet references an incident in Dibrugarh (Assam) where, as police forces came to lathi-charge them, protesting anti-CAA students sang the national anthem, Jana Gana Mana (I think Tagore would have approved!)

LZ: You also direct the poem towards the future, with the wonderful evocation of the little baby girl Umme Habeeba, ${ }^{13}$ "our oldest, finest reason for dissent" you write, and perhaps our "finest reason for hope?" Barely 6 months ago, I imagine that so many people in India (and abroad) thought that things would change, that there was reason for hope. And then 
came the lockdown, and now the government's criminalization of so many of those who took part in these peaceful protests..

$\mathrm{KN}$ : Yes, in that last couplet, it was also an exhortation to myself to remember that we are not just fighting for today, we are fighting for tomorrow. Now it's very tempting to think of what might have happened, if Covid hadn't exploded on the scene. In countries across the world, the one force that this pandemic has helped is the force of absolutism and authoritarianism. It has just made every single abuse secondary in terms of attention and coverage, and also in terms of priority in people's minds. And that's true across the world. Individual rights, freedom of press, the rights of the most fragile sections of society have suffered during the lockdown.

LZ: I wanted to quote the words of writer Githa Hariharan, who is also the co-founder of this extraordinary platform, The Indian Writers' Forum, to which you have contributed. ${ }^{\mathbf{1 4}}$ In a text written for the $3^{\text {rd }}$ anniversary of Gauri Lankesh's brutal murder, she paints a very dark picture of the situation in India today, with the growing list of political prisoners languishing in prison without trial, the attacks on Muslims, minorities, academics, students; the charges of sedition, conspiracy, contempt of court or "unlawful activities" levelled at many citizens. And yet, she says "we still have voices that speak up": "If we speak, Gauri will continue to speak... They cannot silence us all."

KN: I really think The Indian Writers Forum has been doing a wonderful job for so many years as a sentinel. It reminds me of that old saying about those who stay awake, so others can sleep in peace. Now I don't think anyone of us can sleep in peace right now, but the IWF has been there as the eyes in the dark for so long. And they are putting what they see in the dark out there. And that's precious. I think we also have to remember that it's extremely fragile... Remember that whether through fiscal legislation, or through other means, so many NGOs in India are under increasing threat. And for years I was not able to give a donation to IWF because I am a foreign national. The irony of it is that political parties can receive unlimited foreign funding without any examination or questioning, but NGOs are suspect. So even when you are not hounding an organization actively, you are cutting off its blood supply. In other words, supporting something like IWF is more and more vital.

More generally, I think, yes, we have to resist and speak up a long time before we are on our knees. There is so much that we have to be constantly vigilant about. Here as well (i.e. in France). A few months ago, I heard someone who is a leftist and an activist say that he was going to vote Marine Le Pen in the next election, because he said, "it can't get much worse." And I said, it can get much worse. You are a straight, white man in your 70s. Yes, things are going to be ok for you on a quotidian level. But for anybody who is different in any way, in terms of race, in terms of sexuality, in terms of language, in terms of religion, in terms of dissent or mobility, no it is not going to be ok. The alternative cannot be the Marine Le Pens of the world, because India is standing testimony to how little it takes to dismantle a democracy. 5 years! When you had 65 years behind you... What I mean is all you need is the wrong regime in power, in both houses of the Parliament, with enough clout to purchase or threaten free press. No country is invulnerable in its democratic or republican principles.

LZ: I'd like to raise with you the question of literary texts as responses or reactions to specific events. Of course, you cannot predict from where a poem really springs, and a writer always writes with everything he or she experiences, but you've written many poems that seem to articulate a kind of response, like your ghazal around Shaheen Bagh, or your powerful text on the Charlie Hebdo and November 2015 attacks in Paris in Over and 
Underground in Paris \& Mumbai. You also wrote a recent poem triggered by a self-portrait of the photographer Khadija Saye, ${ }^{15}$ who was killed in the Grenfell Tower fire...And that made me think of a short newspaper column written by Adil Jussawalla called "Poems after Ayodhya,"16 where he takes issue with the fact that you should expect poets to voice their immediate protest or shock about the riots. And he has this fabulous sentence where he writes that "the state of the country is not a workshop that makes poems happen..."

$\mathrm{KN}$ : Bless him! But, whether we like it or not, poetry is political. Take the Romantic movement, for instance, which all seems very innocuous, but for me was intensely political as well, because you were taking the divine out of the established places and the realm of religion, and placing it in nature for instance, or within the discovery of a wider world. But I agree completely with Adil and do get uncomfortable with poems that are for example titled "Kargil" or "Palestine." And very conflicted about what one could call a form of disaster porn. But it's sensitive, isn't it? And I always think of something Larbi (Sidi Larbi Cherkaoui) told me: should me no shoulds, in other words, let there be no rules on what can or cannot be tackled by art. So I also think that everyone responds as he or she can, and the poem will speak for itself. Nothing should come between that compulsion to speak and the page, if you see what I mean. My own take is that I try to situate it in the intersection between the personal and the political and that's the way it's been for Charlie Hebdo for instance...Even today, I mourn Bernard Maris ${ }^{17}$ like somebody I knew. And so I write also from a very personal space, of what I lost in that bloody massacre.

LZ: That's exactly, in fact, what Jussawalla was saying in that article. He writes "the voice of a poet may have its very roots in historical violence that has become personalized." To be more precise, his point was that if the state of the nation is indeed not "a workshop" that makes poetry happen, it's because it doesn't make poetry happen at one time, and not at another. It always makes poetry happen, which means, in a sense, that poetry is always political

KN: Yes, and to return to the poems on Charlie Hebdo and the November attacks in Paris, it took me months, even I'd say an entire year, before I could articulate how I felt to begin with, about Bernard Maris. And it took me about two and a half years before I could talk about what happened on rue de Charonne, and again it's about the guilt of not being there, because I was supposed to be on that street with Damien, ${ }^{18}$ and the poem is about him. But, look, more than anything else, more than time and more than history, I believe in what Jeannette Winterson said, which is that poetry can give pain a mouth. Yes, that is what poetry lets me do.

LZ: In the context of Until the Lions, and your recasting of the Mahabharata, you've said in an interview that Manichaeism is the poison of epics, because they give form to many shades of human nature, and dissolve the predicable binaries of "black" and "white," heroes and villains ${ }^{19}$. And I was thinking that the vocation of the writer is also to nurture complexity, to produce works of art that are open to an inexhaustible plurality of interpretations, or gazes as you say, and perhaps also to struggle, I am here paraphrasing the writer Amit Chaudhuri, against visible, definite or content-driven markers... So how do you reconcile the writer and the activist within you, and is that a question that you find relevant, if at all?

KN: I never feel the need to reconcile the two because I don't make a distinction, for myself. But once again, those are personal choices. When Arundhathi Roy talks about the hyphenated writer, i.e. writer-activist, and says that it is a tautology for her, I totally get that, and in a sense abide by that. Because, you see, for all intents and purposes, The Honey Hunter, ${ }^{20}$ which is in principle a children's book, is no less political than Until the Lions. The Honey Hunter comes from a very localized cosmogony, which for me is as important as "majoritarian" Islam or Hinduism; it is a 
syncretic story, it's about a land (the mangrove forests of the Sundarban) where a Goddess can be Hindu and Muslim at the same time; it's about a land which is extremely fragile, which is between fresh water and sea water, which is both land and water, and which is the first line of defense against external dangers (cyclones, floods) but is also increasingly vulnerable (from oil spills, from new coal plants polluting the river...) and, we humans are utter jackasses if we don't recognize that. And if I can say that to a child without any time pamphleteering, my job is done.

The story also raises the question that if we need to redeem ourselves as a race, we need to, at least in some ways, undo the damage that we've done to the planet, which is what the child in the story has to do. Of course, solutions have to be found which are not as simple in our lives as in a fable, but the little boy in the story has to undergo a transformation and a great deal of suffering to try and compensate in some ways for the destruction that he's brought. So, you know, how is The Honey Hunter not political?

LZ: Your poems are often put to music or staged. And you've said that the good thing about scripting for dance is that it teaches you that your words are no more and no less than raw material to be used by others. That you can't own them. I'd love to follow up on that idea with you, because of course that goes against the Hindutva attempts at "governing those who undertake the telling of stories," to cite the poet Jeet Thayili, ${ }^{\mathbf{2 1}}$ and goes against all those who want to decide on which story is true, or legitimate and who has the right to tell it, or claim custody over it. I know you've spoken about this before, but since Until the Lions was also about challenging majoritarian narratives, would you like to tell us again how it was connected to that specific context?

KN: Let's put it this is way. So many people have said it so much better than I ever can, but the Mahabharata is part of a tradition that has thrived in its multiplicity. There are Mahabharatas all across Asia. Characters change, equations change, morality changes. What's wonderful about the Mahabharata for me, is that it's much more revelatory of the time and place in which it is told, it really mirrors the preoccupations, or the defenses, or the reclamations of that particular localized humanity. And for me all these Mahabharatas are valid. And the attempt that every majoritarian power, every totalitarian regime makes, which is to homogenize narrative, has to be resisted at all cost.

Until the Lions was primarily driven by the desire to show that the landscape changes depending on where you stand. Like I've said, when you are at the rim of the battle, it looks very different from where you are in the thick of it, surrounded by bodies. It's a very different vision of "glory" or "heroism" than it is for someone who is sitting on a throne and just listening to a narrative of how much has been gained or lost, or someone who listens to this victorious poem 2000 years later and decides to reclaim it because there is some golden past that they want to connect to. So, the poems are about that as well.

LZ: But when you were writing Until the Lions, were all the controversies surrounding those who like the painter M. F. Husain, or the writer and translator A. K. Ramanujan, have retold these epics or celebrated their multiplicity, and have been hounded or censored for those very reasons, at the back of your mind?

KN: All that was there. But when I wrote Until the Lions, I needed to be true to each voice, to inhabit all these different voices. And you know the India I grew up into was so much more plural than it is now...But I guess it helps to live in France, with a government whose default position is not "you should be behaving yourself as a 
writer." It's great not to have strictures about what you can, or cannot write. Yet, once again, while I was writing it, it was a process of immersion and the only thing that inhabits each poem is hopefully the voice of the person it should be. Now, is that person in an a-historic and insulated world? No. For me that person could be here and now. And Sauvali ${ }^{22}$ is a Dalit woman today as much as a mythological character in a non-existent kingdom. And when I wrote Sauvali was I thinking about all the Adivasi women whose rights to their own bodies have been violated? Yes. Actually, Sauvali could also be an upper-caste woman who is told that she has to bear sons.

Now to return to the earlier part of our conversation about forms as weapons, poetry came to my rescue with its panoply of forms that are windows of expression with they own history. They also allow you to occupy a different space, and in the case of Until the Lions, try to become something else...

LZ: Is that also why you say in your preface to the American edition that the imagination is the most priceless gift to give up, because that may be the only way you can understand "what it is to be another?"

KN: Yes. And when I also write that "there are no small freedoms," I really cannot emphasize that enough. I think that India is unfortunately right now living proof for anybody who wants to see the chronicle of an ascension of totalitarianism. This is the chronology: the loss of greater freedoms comes in the slipstream of the denial of perceived "smaller" freedoms. It's an incremental approach. First, almost always, they come for the books, the art, the movies, the seemingly frivolous things. I would trace it all the way back to the first book banned in independent India, whatever the reason. Because if you can police the imagination, control the freedom of the mind, then everything else will fall in line. There can never be adequate protection for, or vigilance over, these.

LZ: One last question, Karthika. I wanted to hear you more specifically, on the place of women, women voices and women bodies, both in your texts and also at Shaheen Bagh. You just mentioned Sauvali whose voice is one of the most moving, raw, and chilling accounts of a rape that has been institutionalized-even sanctified. Let me quote a few lines from that poem: "when the king decides to rape me or my kind. No one will use the word rape. The word does not exist in the king's world. This body is just another province he owns, from navel to nipple, to eyelid, insole to clitoris.". And your poetry, in its impossible-toeuphemize crudity, often returns to these women bodies. I wonder if you would like to say a few words on the subject, and perhaps connect the space cleared by women in Shaheen Bagh to the space cleared by these women voices in your poetry?

$\mathrm{KN}$ : The women in Until the Lions-also the animals and foot-soldiers (everyone at the lowest end of the pecking order, actually, of the Hindutva-ed society, which reinforces caste verticality, and is obsessed with upholding the varna system)-are standing up to be more than detritus, more than possessions, which is the position that they get reduced to, all too often. They have known for millennia that they are, as I have said over and over, the first casualties of war and conflict. Their bodies will be reclaimed by those in power, sometimes through the apparatus of religion, or morality, sometimes through brute force. Let's look around us, through history, from ancient times till now-whichever the religion, whichever the power-the pursuit of ownership of women's bodies and freedoms is probably the commonest denominator among them, from Trump's America to Taliban Afghanistan to Hindutva-proud India. The characters, especially the women, in Until the Lions are responding in a variety of ways to that project of ownership. Amba takes up arms herself. Others, like Sauvali, 
react in quieter, but just as radical, ways: Sauvali's position is that the king may own her body, her child, but he cannot own her thoughts, nor her conscience: and that is the legacy she leaves her son, to give him the strength to revolt, to leave the king who fathered him but would not give him legitimacy.

Also, as we've discussed before, I also focussed on the female voice because they had narratives that went beyond victory and defeat, they were invested in survival, safety, growth, well being. They were witnesses and they brought memory to the fore to reclaim legitimacy. That, for me, defines Shaheen Bagh and its women: they wanted legitimacy for themselves, their kin, their communities, their sisterhood-for their country. One of the things they reminded us of with such quiet dignity is this: it is their country too. And the legitimacy of citizenhood is a fundamental right (as Romila Thapar said recently, that is what distinguishes a free nation from a colony: we are not subjects anymore). The women of Shaheen Bagh held themselves as witnesses of an age-old pact between government and its people. There are few things more sacred, in a secular world.

\section{NOTES}

1. Karthika Naïr was the principal scriptwriter for Akram Khan's award-winning dance-drama production DESH in 2011 (and its adaption for younger audiences, Chotto Desh, in 2015).

2. Until the Lions was partially adapted by Akram Khan for his acclaimed piece of the same name which premiered in 2016. An opera based on Until the Lions and directed by Shobana Jeyasingh, was also due to open in March 2020 at the Opéra National du Rhin. It was postponed to September 2022 due to the Covid Pandemic.

3. David Shulman. 2020. "The Widows' Laments." The New York Review of Books. September 24. Retrieved September 202020 (https://www.nybooks.com/articles/2020/09/24/mahabharatawidows-laments/).

4. For many Indian writers and cultural practitioners, 2015 seemed to have represented a turning point. 2015 was the year that author and activist Govind Pansare as well as scholar and Sahitya Akademi awardee M.M. Kalburgi were gunned down (and this came after the murder of rationalist activist and writer Narendra Dabholkar in 2013) and the year Mohammed Aklaq was lynched by a mob for "eating beef" in Dadri. Several writers returned their state awards as a mark of protest, and this snowballed into a nation-wide movement, which also served as a catalyst for the creation of the "Indian Cultural Forum." One of its co-founders, Githa Hariharan, speaks of the 2015 moment as a "memory to teach us how we, people sitting alone somewhere, writing or painting or whatever, can be a vital part of a public debate or protest" (Zecchini, Laetitia. 2017. “'We are Talking of More than Writers' Rights, we are talking about letting people live': An Interview with Githa Hariharan." July 14. Writersandfreeexpression. Retrieved October 27, 2020 (https://writersandfreeexpression.com/2017/07/14/we-are-talking-of-more-than-writersrights-we-are-talking-of-letting-people-live-an-interview-with-githa-hariharan/).

5. Karthika Naïr. 2020. Until the Lions: Echoes from the Mahabharata. Archipelago Books, USA (See Author's Note, pp. 2-9). 
6. Writer, journalist, human rights activist and current Chair of Pen Writers in Prison Committee, Salil Tripathi has written several books including Offence: The Hindu Case (Seagull Books, 2009) and The Colonel who Would not Repent: The Bangladesh War and Its Unquiet Legacy (Yale University Press, 2016). On Salil Tripathi's work and biography, see Zecchini, Laetitia. 2017. “From a Very Young Age, I used to Collect Books that were Banned': An Interview with Salil Tripathi." Writersandfreeexpression.2017 : https://writersandfreeexpression.com/2017/09/27/from-a-veryyoung-age-in-fact-i-used-to-collect-books-that-were-banned-an-interview-with-salil-tripathi/

7. Shahidul Alam was imprisoned for more than three months in 2018 under Section 57 of Bangladesh's Information and Communication Technology Act, ostensibly for a Facebook post criticising the government crackdown on students and citizens protesting inaction over increasing road safety lapses.

8. Varavara Rao is a prominent intellectual, a famous Telugu poet and a political activist who was arrested and imprisoned in 2018 under the Unlawful Activities Prevention Act (UAPA), for his alleged Maoist links. Saibaba, a Delhi University English Literature Professor was imprisoned in 2014, likewise for his alleged links with the CPI(M). On the international appeal, see The Wire Staff. 2020. "Nearly 100 Global Intellectuals Appeal for Varavara Rao, Saibaba to be Released." The Wire, June 14. Retrieved September 5, 2020 (https://thewire.in/rights/global-intellectualsappeal-saibaba-varavara-rao-release).

9. For instance, in the first three couplets, the qafiya is the following pattern of words: "nation," "beacon," "horizon.".

10. The poem "Who Kaghaz kahan se laaon" (Where do I find the Documents) penned by lyricist Kaunsar Munir is available on Scroll.in. February 28, 2020. Retrieved September 26, 2020 (https:// scroll.in/video/954506/watch-writer-kausar-munirs-heartrending-and-heartwarming-poem-

woh-kaghaz-kahan-se-laaoon)

11. When the IIT Kanpur faculty and students sang "hum dekhenge" to protest and show solidarity with the students of Jamia Millia Islamia, other faculty members came together to file a complaint. The Wire Staff, 2020. "IIT Kanpur Panel Says Reciting Faiz' 'Hum Dekhenge' was 'unsuitable to Time, Place." The Wire, March 16. Retrieved September 26, 2020 (https:// thewire.in/rights/faiz-ahmad-faiz-iit-kanpur-hum-dekhenge)

12. "Everything will be remembered / Kill us, we will become ghosts / and write of your killings... We will speak so loudly that even the deaf will hear / We will write so clearly that even the blind will read / You write injustice on the Earth / We will write revolution in the sky."

13. Umme Habeeba was described by the press as the youngest of all "protesters" present at Shaheen Bagh. Barely a month old, the baby girl was brought to the protests by her mother. She is mentioned in Samrat Chakrabarti. 2019. "Shaheen Bagh Heralds a New Year with Songs of Azaadi." The Wire, December 31. Retrieved September 26, 2020 (https://thewire.in/rights/delhishaheen-bagh-anti-caa-protest).

14. See The Indian Cultural Forum website (https://indianculturalforum.in/) and "'We are Talking of More than Writers' Rights, We are Talking about Letting People Live': An Interview with Githa Hariharan," art.cit.

15. Karthika Nair. 2020. “Tééré, 2017," Visual Verse: An Anthology of Arts and Words, Vol 07, Chapter 09. Retrieved July 4, 2020 (https://visualverse.org/images/khadija-saye/).

16. Adil Jussawalla. 1993. "Poems after Ayodhya," republished in Pinto, Jerry (ed.). 2014. Maps for a Mortal Moon, Essays and Entertainments. New Delhi: Aleph Company, (pp. 275-77). I thank Vidyan Ravinthiran for drawing my attention to that particular text again.

17. Bernard Maris was a well-known French journalist, writer and economist who was murdered on 7 January 2015 when the Kouachi brothers stormed into the Charlie Hebdo headquarters, and killed twelve people, including many senior members of the editorial staff.

18. Choreographer and dancer Damien Jalet, whose earlier work Karthika Naïr produced. He narrowly escaped the November 2015 attacks in Paris, when gunmen opened fire on the terrace 
of a restaurant on rue de Charonne, killing twenty-one people. Other attacks unfolded that same night in other parts of Paris, where more than 130 died.

19. See, amongst other interviews, the very interesting two-part conversation between Jai Arjun Singh and Karthika Naïr in 2015: "We can Often be Hero to One Person, Villain to Another and Something in Between to Lots of Others." Scroll.in. September 6. Retrieved September 26, 2020 (https://scroll.in/article/753741/we-can-often-be-hero-to-one-person-villain-to-another-andsomething-in-between-to-lots-of-others).

20. For a short, animated preview of The Honey Hunter in French, see: https://vimeo.com/ 76849166

21. Jeet Thayil. 2015. "Rules for Citizens." Pp.14 in Collected Poems. New Delhi: Aleph Book Company.

22. Sauvali, one of the 19 characters and voices of Until the Lions, who is chosen as a concubine and raped by Dhritarashtra, speaks in the poem "Bedtime Story for a Dasi's Son."

INDEX

Keywords: Karthika Naïr, Shaheen Bagh, (protest) poetry, literary activism, ghazal

\section{AUTHORS}

\section{LAETITIA ZECCHIN}

Centre national de la recherche scientifique 